
ILIŞKININN DE ĞERLENDİRILMESI

1 SBÜ Konya Eğitim ve Araștırma Hastanesi, Çocuk HematolojiOnkoloji Kliniği, Konya

2 Sivas Cumhuriyet Üniversitesi Tıp

Fakültesi, Çocuk ve Ergen Psikiyatrisi Ana Bilim Dalı, Sivas

Sorumlu yazar yazışma adresi:

Utku AYGÜNEŞ: SBÜ Konya Eğitim ve Araştırma Hastanesi, Çocuk Hematoloji-Onkoloji Kliniği, Konya, Türkiye

E-mail: utkuayg@gmail.com

Geliș tarihi/Received: $\quad 06.05 .2020$ Kabul tarihi/Accepted: 15.05.2020 Yayın hakları Güncel Pediatri'ye aittir.

Güncel Pediatri 2020;18(2):194207

\section{The Association Between Loss Of Appetite And Sense Of Olfaction In Children With Iron Deficiency Anemia}

Utku Aygüneş(0000-0001-9903-2923) ${ }^{1}$, Ayla Uzun Çiçek(0000-0003-2274$3457)^{2}$

\section{$\ddot{O} Z$}

GİRIŞ̧ ve AMAÇ: Çocukluk çağında en sik görülen anemi türü olan demir eksikliği anemisi (IDA) varlığının koku alma davranışını ve IDA'lı hastalarda koku duyusunun iştah durumunu nasıl etkilediği hakkında çok az şey bilinmektedir. Bu çalışmanın amacı; IDA'lı hastalarda koku duyusundaki değişiklikleri ve koku duyusu değişikliklerinin iştah üzerine etkisini ortaya koymaktır.

YÖNTEM ve GEREÇLER: Çalışmaya IDA tanılı 57 çocuk ile herhangi bir psikiyatrik bozukluğu ve anemisi olmayan, hasta grubuyla yaş, cinsiyet, sosyokültürel özellikler ve eğitim durumu açısından eşleştirilmiş 57 sağliklı çocuk dahil edilmiştir. Koklama fonksiyonu ölçümü için Sniffin koku duyusu çubukları kullanıldı. Değerlendirme, Sosyodemografik Veri Formu, Duygusal Bozukluklar için Kiddie Takvimi ve Okulda Yaşanan Çocuklar ve Yaşam Boyu Versiyon için Çocuk Şizofreni ve Çocuk Yeme Davranışı Anketi kullanılarak yarı yapılandırılmış bir psikiyatrik görüşme kullanılarak gerçekleştirilmiştir.

BULGULAR: IDA'l1 hastalar, kontrol grubuna kiyasla anlamlı olarak daha düşük bir eşik, ayrımcılık ve tanımlama değerine sahipti. Korelasyon analizi, toplam koku testi skorundaki artış ile iştah göstergeleri toplam skoru arasında anlamlı bir korelasyon gösterdi.

TARTIŞMA ve SONUÇ: : $\mathrm{Bu}$ çalışmada IDA'lı çocuklarda, iştah azalmasına koku fonksiyonlarında bozulmanın eşlik ettiği görülmüştür. Koku işlev bozukluğunun, iştah azalması açısından önemli bir faktör olabileceği düşünülmektedir

Anahtar Kelimeler: İştah, çocukluk çağı, demir eksikliği anemisi, koku 


\section{ABSTRACT}

INTRODUCTION: IDA (iron deficiency anemia) is the most common type of anemia in pediatric patients and very little is known about the effect of IDA on the sense of smell and about the effects of smell on appetite. This study shows the effect of IDA on the sense of smell and about the effects of smell on appetite.

MATERIALS and METHODS: The study enrolled 57 IDA patients and 57 healthy subjects. Olfactory function was evaluated using the Sniffin' Sticks olfactory test. The evaluation was performed by using a semi-structured psychiatric interview using Sociodemographic Data Form, Kiddie Schedule for Affective Disorders and Schizophrenia for School Aged Children-Present and Lifetime Version and The Child Eating Behaviour Questionnaire.

RESULTS: Patients with IDA had a significantly lower threshold, discrimination, and identification value, and a lower threshold compared with the control group. Correlation analysis showed a significant correlation between an increase in the total olfactory test score and the total score for appetite indicators.

CONCLUSIONS: In this study, it was observed that decreased appetite in children with IDA was accompanied by impaired odor functions. It suggests that odor dysfunction may be a significiant factor for decreased appetite.

Key words: Appetite, childhood, iron deficiency anemia, olfaction 


\section{INTRODUCTION}

Anemia is defined as the decrease in hemoglobin concentration per millimeter cube, hematocrit, or erythrocyte number. The prevalence may exceed $50 \%$ in lower socioeconomic groups. Iron deficiency anemia is thought to represent the most common cause of anemia in all age groups in general, and in pediatric patients in particular [1].

Signs of symptoms of anemia include the general manifestations such as paleness, fatigue, tiredness in addition to psychological, neurological, and mental consequences such as irritability and agitation, attention deficit, learning difficulties, anxiety, and depression. Therefore, anemia may lead to both psychomotor and mental impairment in children [2,3].

Appetite is the psychological need and desire to eat that is probably a learned phenomenon associated with pleasant taste, smell, and satisfaction. On the other hand, loss of appetite is a common finding in anemia and therefore it has been recommended that anemia be investigated in children with reduced appetite [4]. Also, reduced appetite and nutritional problems may represent a clinical sign in many psychiatric disorders of childhood [5].

IDA is the most common type of anemia in pediatric patients and very little is known about the effect of IDA on the sense of smell and about the effects of smell on appetite. Our literature search has not revealed any studies examining the effect of IDA on the sense of smell and the effect of smell functions on appetite in pediatric and adolescent patients. However, two related studies were identified, one examining the effect o anemia on the sense of smell in rats [6], and the second in adult patients in 2016 [7]. In both studies, IDA was found to be associated with reduced and modified sense of smell. On the other hand, others have already suggested the presence of specific alterations in both appetite and sense function in some psychiatric disorders of the childhood such as depression, attention deficit hyperactivity disorder, and anxiety disorders [8].

Therefore, in this study we compared differences in smell function between the two following pediatric groups: 1) patient group (Group 1, $\mathrm{n}=57$ ) with IDA but no psychiatric disorders; and 2) the control group (Group 2, n=57) consisting of healthy children and adolescents. 


\section{MATERIALS and METHODS}

This cross-sectional study was carried out at the Pediatric Hematology Unit of Cumhuriyet University Hospital, Sivas, Turkey with the inclusion of outpatients diagnosed with anemia. Ethical approval was provided from the Human Research Ethics Committee of Cumhuriyet University, Sivas, Turkey before the study. Initially eighty one children diagnosed with IDA were included in the study. However there were 24 drop-outs: 8 parents refused to participate due to either parents' shortage of time, and sixteen patients were excluded because they did not meet the study inclusion criteria or either failed to understand or complete the task. So, fifty-seven children diagnosed with IDA but no psychiatric disorders (22 male, 35 female; mean age: $12.61 \pm 2.3$ years, min-max: 8-16 years) and 57 healthy children (22 male, 35 female; mean age $12.75 \pm 2.41$ years; min_max: 8-16 years) matched with the patient group in terms of age, gender, socioeconomic background, and education were included. All participants $(n=138)$ were enrolled between March 2019 and July 2019. After the option to participate was offered and written informed consents were received, a total of 114 volunteers were included in the study. Exclusion criteria were any conditions known to cause olfactory dysfunction such as allergies or medications, acute and chronic diseases of the ear, nose or throat, cystic fibrosis, history of epilepsy, traumatic brain injury, drug or alcohol abuse, smoking.

We further excluded children with neurological findings such as motor dysfunction, difficulty in swallowing, irritability or any organic neurologic disorder, and comorbid psychiatric disorders including intellectual disability, cognitive dysfunction, somatization and depression, and all patients were untreated at the time of testing. Parental consent and patient assent were obtained from every family during the interview.

Initial assessment was performed by a pediatric hematology specialist. Then, participants and their parents underwent a face-to-face psychiatric interview in order to identify whether the child has any current and past psychiatric disorder. The evaluation lasted about 30 minutes and was performed by a certified child \& adolescent psychiatrist using a semi-structured psychiatric interview $[9,10]$.

Data Collection and Tests Administered

Sociodemographic Data Form: This form was developed by the investigators to assess the sociodemographic characteristics of the study participants.

Kiddie Schedule for Affective Disorders and Schizophrenia for School Aged Children- 
Present and Lifetime Version (K-SADS-PL): K-SADS-PL is a semi-constructed diagnosis interview in order to identify previous and current psychopathologies in children and adolescents according to DSM III and DSM IV diagnosis criteria [9]. Validity and reliability in Turkish cohort was reported by Gökler et al [10]. K-SADS-PL evaluates previous and current symptoms as "absent", "subthreshold" and "present" and do not inform about the severity of symptoms.

The Child Eating Behaviour Questionnaire (CEBQ): CEBQ was designed by Wardle et al. to assess children's eating scale styles [11]. The reliability and validity studies of the Turkish version were carried out by Yilmaz et al. [12]. This is the most comprehensive measure to evaluate the eating styles and behaviour in children that comprises 35 items. It is made up of eight scales: Food responsiveness, Emotional over-eating, Enjoyment of food, Desire to drink, Satiety responsiveness, Slowness in eating, Emotional under-eating, and Food fussiness [12]. The extended version of the Sniffin' Sticks Test (SSET) (Burghart GmbH, Wedel, Germany): The Sniffin' Sticks extended test was administered as described in the literature [13]. Specifically, the three different tests were assessed in the following order: odor detection threshold; discrimination; and, identification. Odorless gloves were worn by the experimenter during the test.

a) Olfactory Detection Threshold Task: The olfactory detection threshold task includes 16 dilutions starting from 4\% n-butanol solution (ratio 1:2 in deionized water). Prior to the test, study subjects were exposed to the pen stick with the highest n-butanol concentration. The investigator asked the participants to identify the pen stick containing the n-butanol in each of the trials. The test was terminated when a series of seven descending and ascending trials were completed. The mean of the last four trials was defined as the olfactory threshold. The scores could range between 16 (subjects who were able to detect the lowest concentration) and 1 (participants who were unable to detect even the highest concentration). b) Odor Discrimination Task: The odor discrimination task is based on a series of 16 triplets: two pen sticks containing the identical odor (non-target) while the last one has a different odor (the target). Subjects were asked to identify the target odor in each test round consisting of triplets. The stimuli was administered with $30 \mathrm{~s}$ intervals. Each of the trials was scored as correct (a score of 1) or incorrect (a score of 0 ). The total score (ranged between 0 and 16) for each patient was calculated a as the sum of the correct discrimination responses.

c) Odor Identification Task: Odor identification was assessed by presenting a series of 16 pen sticks, containing odor stimuli consisting of natural scents. Participants were asked to identify 
the odor from a list containing four possible choices (one target and three non-targets). Stimuli were administered with 20-30 s intervals. Each item was scored correct (score $=1$ ) or incorrect (score $=0$ ). The total score for each participant was based on the sum of the correct identifications. The total score ranged between 0 and 16 for each patient.

Threshold, Discrimination, and Identification Score: The threshold, discrimination, and identification (TDI) score represents the sum of odor detection threshold, discrimination, and identification values. This score ranges from a minimum of 1 to a maximum of 48 .

Statistical Methods: The study data was assessed using SPSS 23.0 software pack. The normality of the data was evaluated using the Kolmogorov-Smirnov test. The association between variables were determined with Pearson's correlation coefficient for parametric variables, and Spearmen's correlation coefficient for non-parametric variables. The chi-square test was utilized for the evaluation of the categorical variables. The error of margin was set at 0.05 .

\section{RESULTS}

Patient and control subjects did not have a significant age difference $(12.61 \pm 2.3$ and $12.75 \pm$ 2.41 years; $\mathrm{p}=0.734$ ). As expected, IDA patients had lower $\mathrm{Hb}$ (mean 10.61 $\pm 0.99 \mathrm{~g} / \mathrm{dl}$ ), hematocrit (mean 34.24 \pm 3.97 ), MCV (mean 71.13 \pm 7.58 ) and serum iron levels (mean $32.05 \pm 13.49)(\mathrm{p}=0.000$, for each). TIBC was elevated in the patient group (297.89 \pm 60.82$)$ $(\mathrm{p}=0.000)($ Table 1$)$.

Table 1. Basic statistical data for the patient and control groups.

\begin{tabular}{|ll|c|c|}
\hline & $\begin{array}{c}\text { Patient group } \\
\text { Median (Min-Max) }\end{array}$ & $\begin{array}{c}\text { Control group } \\
\text { Median (Min-Max) }\end{array}$ & $\boldsymbol{p}$ \\
\hline Age & $12.61 \pm 2.3 \quad(8-16)$ & $12.75 \pm 2.41(8-16)$ & 0.734 \\
\hline Hemoglobin & $10.61 \pm 0.99(8.3-11.9)$ & $14.58 \pm 0.77(13.5-16.7)$ & 0.000 \\
\hline Hematocrit & $34.24 \pm 3.97(25.6-42)$ & $43.92 \pm 2.77(40.1-50.8)$ & 0.000 \\
\hline MCV & $71.13 \pm 7.58(54.9-87.3)$ & $84.58 \pm 4.65(68.5-93.8)$ & 0.000 \\
\hline Serum Iron & $32.05 \pm 13.49(9-61)$ & $99.22 \pm 20.55(61-157)$ & 0.000 \\
\hline Ferritin & $11.14 \pm 6.58(2-26)$ & $29.48 \pm 10.91(14-53)$ & 0.000 \\
\hline TIBC & $424.89 \pm 52.1(308-575)$ & $297.89 \pm 60.82(150-400)$ & 0.000 \\
\hline
\end{tabular}

MCV: mean corpuscular volume; MCH: mean corpuscular hemoglobin; TIBC: total iron binding capacity. 
Based on the CEBQ results, patients scored significantly lower in all appetite indicators (food enthusiasm, excessive enjoyment of food, extreme emotional overeating, drinking passion) as compared to controls. On the other hand, indicators of reduced appetite such as toughness enthusiastic, slowness in eating, emotional less eating, and food selectivity scores were significantly higher among the patients than in controls $(\mathrm{p}=0.000)$ (Table 2).

Table 2. The Child Eating Behaviour Questionnaire scores for the patient and control groups.

\begin{tabular}{|c|c|c|c|c|}
\hline \multirow{2}{*}{ Excessive appetite indicators } & $\begin{array}{c}\text { Patient group } \\
\text { Median }\end{array}$ & \multicolumn{2}{|c|}{$\begin{array}{c}\text { Control group } \\
\text { Median }\end{array}$} & \multirow[t]{2}{*}{$p$} \\
\hline & & & & \\
\hline Food enthusiasm & $25.08 \pm 2.06$ & $16.24 \pm 3.4$ & 0.000 & \\
\hline Excessive enjoyment of food & $6.29 \pm 1.55$ & $8.5 \pm 2.63$ & 0.000 & \\
\hline Extreme emotional overeating & $71.13 \pm 7.58$ & $84.58 \pm 4.65$ & 0.000 & \\
\hline Drinking passion & $7.22 \pm 1.37$ & $9.29 \pm 2.03$ & 0.000 & \\
\hline Total score & $38.45 \pm 5.48$ & $50.61 \pm 9.74$ & 0.000 & \\
\hline \multicolumn{5}{|l|}{ Loss of appetite indicators } \\
\hline Toughness enthusiastic & $25.38 \pm 3.25$ & $16.78 \pm 3.78$ & 0.000 & \\
\hline Slowness in eating & $8.87 \pm 2.31$ & $8.24 \pm 2.09$ & 0.000 & \\
\hline Emotional less eating & $13.52 \pm 1.46$ & $11.19 \pm 2.02$ & 0.000 & \\
\hline Food selectivity & $7.17 \pm 0.96$ & $9.61 \pm 2.16$ & 0.000 & \\
\hline Total score & $55.33 \pm 5.8$ & $45.03 \pm 5.81$ & 0.000 & \\
\hline
\end{tabular}

Olfactory performance as measured by Sniffin sticks was lower in the IDA patients in all test subgroups (threshold, identification, discrimination) $(p=0.000)$.

An assessment based on the Spearman's correlation analysis showed a significant correlation between an increase in the total olfactory test score and the total score for appetite indicators $(\mathrm{p}<0.005, \mathrm{r}=0.664)$. Again, the same analysis sowed a correlation between lower total olfactory scores and the total scores for loss of appetite $(\mathrm{p}<0.005, \mathrm{r}=0.580)$ (Figures 1 and 2 ). 


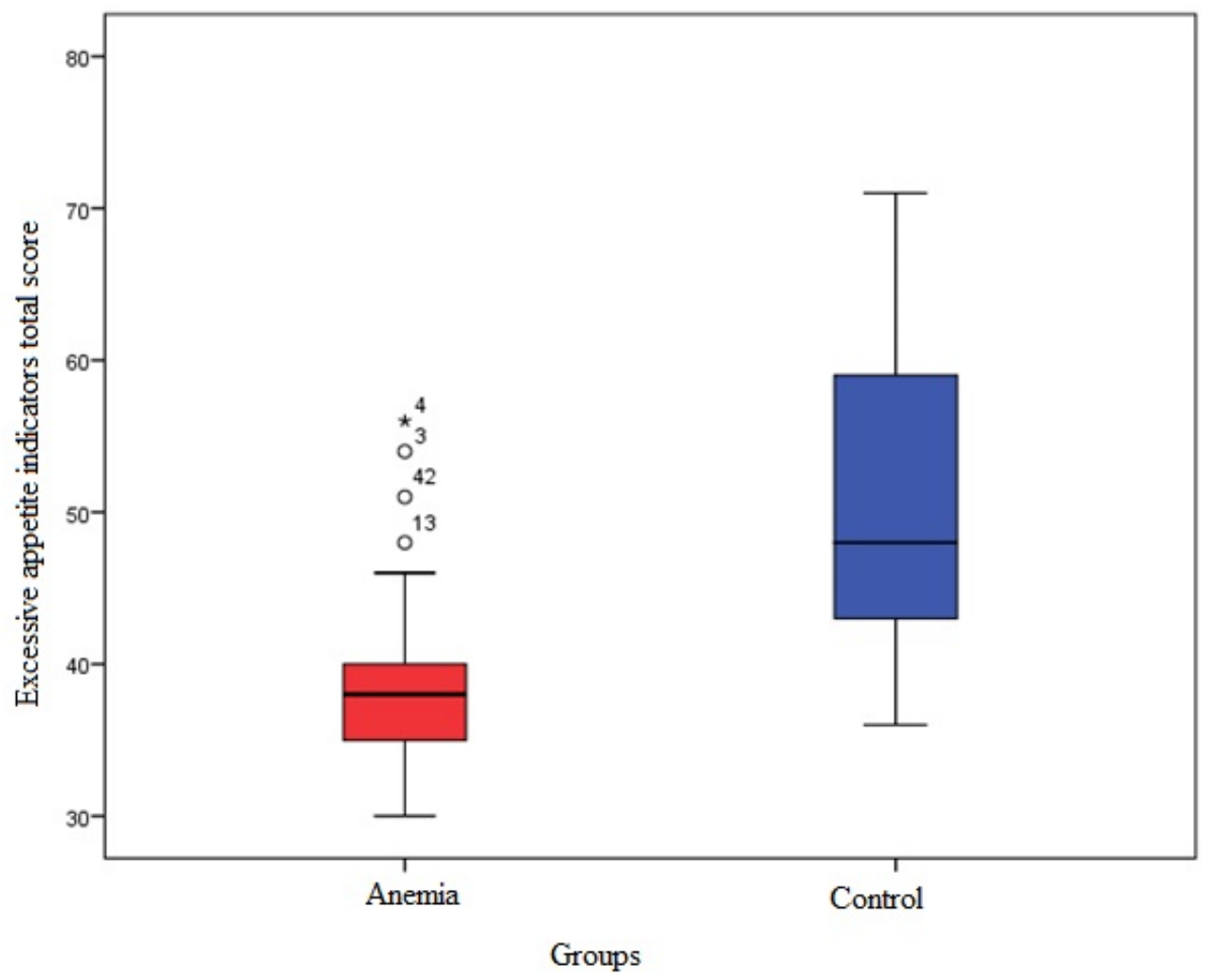

Figure 1. The comparison of excessive appetite indicators total score between the patient and control group.

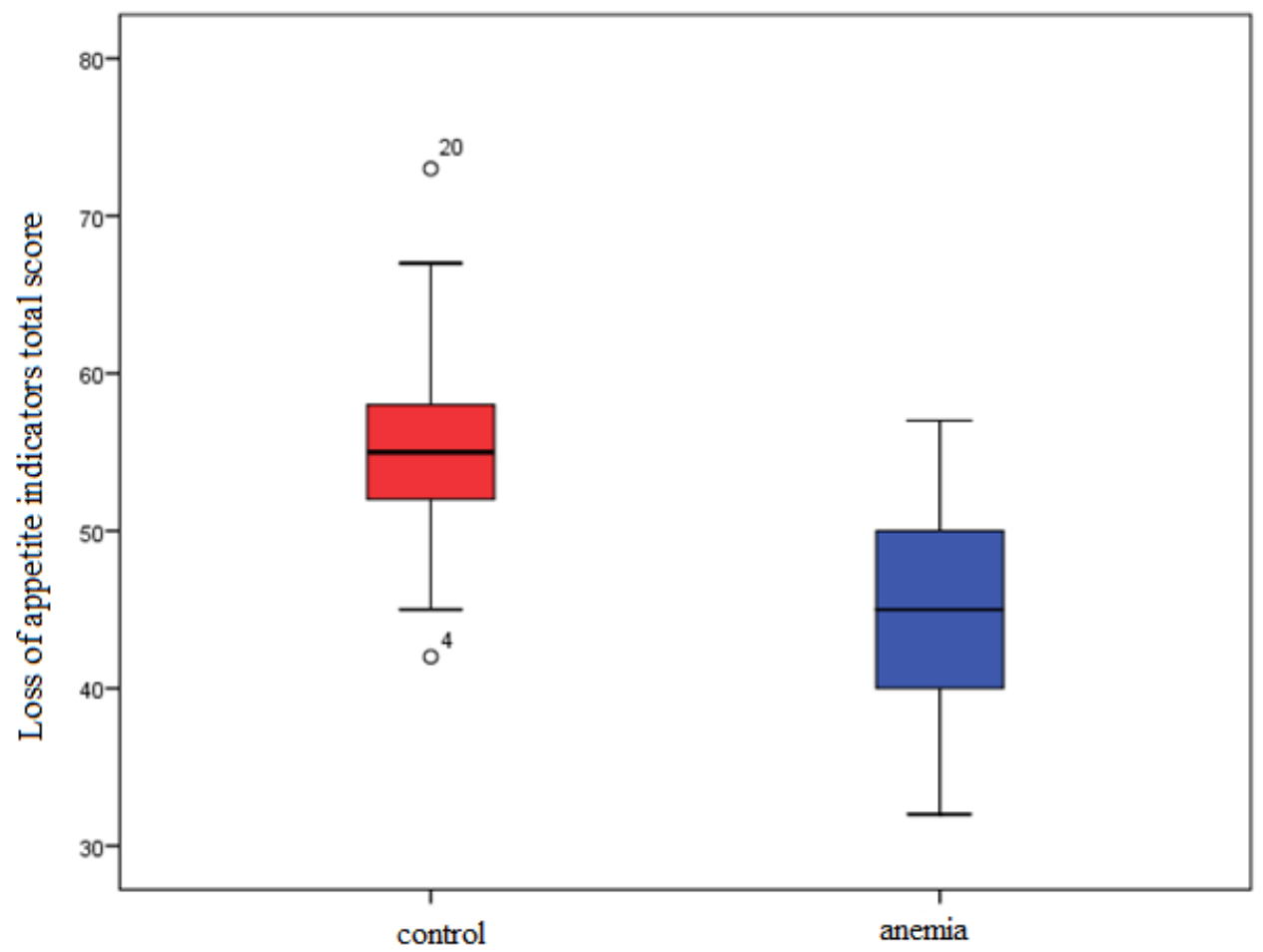

Figure 2. The comparison of loss of appetite indicators total score between the patient and control group. 


\section{DISCUSSION}

To the best of our knowledge, this is the first study to examine the association between olfactory functions and appetite in pediatric IDA patients.

This study was undertaken to evaluate the appetite, effect on olfactory functions, and the relationship between these two. Diseases preventing the transmission of signals to the olfactory area result in an impairment in the sense of smell. Although the effect of IDA on the olfactory system has not been clearly established in clinical studies, several systemic conditions such as the neurodegenerative Parkinson's or Alzheimer's disease are thought to affect the olfactory pathways through deposition of iron in the central nervous system $[6,14$ 16]. However, there is certainly a need for further studies and the data on the effect of IDA on olfactory functions is scarce.

Iron deficiency anemia is a common condition characterized by low iron, ferritin, $\mathrm{Hb}$, hematocrit, and MCV levels due to low serum iron concentrations, leading to increased total iron binding capacity (TIBC). Despite the lack of definitive data, the prevalence of IDA based on WHO 2008 data is $47.4 \%$ and $25.4 \%$ in pre-school and school children [17]. It also represents a major health problem in our country, with prevalence rates ranging between $1.4 \%$ and $62.5 \%$ in different provinces [18].

The relationship between IDA and the olfactory function: The physiology of the olfactory system is quite complex. Of the total airflow passing through the nostrils, approximately $50 \%$, $35 \%$, and $15 \%$ occur through the medial meatus, inferior meatus, and the olfactory region, respectively. Air passing through the olfactory region stimulates the olfactory cells found in the olfactory epithelium [19]. Air reaching the nasopharyngeal region has a temperature of approximately $25{ }^{\circ} \mathrm{C}$ and humidity of $90 \%$ [20]. During the passage at the nasal valves, the airflow pattern may transform into a turbulent flow in parallel with the increase in the airflow [21]. After the smell molecules reach the olfactory region, they need to come into contact with the mucus covering the receptor cells. Cilia is the cellular organelle in each olfactory cell that is responsible for responding to chemical smell stimuli [22].

Smell molecules contacting with the olfactory surface first penetrate into the mucus covering the cilia. Then, these molecules are bound to a receptor protein that projects from the ciliary membrane. This receptor is a long molecule that penetrates the membrane seven times by folding externally and internally throughout the membrane. The smell molecule binds to the external surface of the folded receptor, while the internal surface of the receptor is coupled to 
a G-protein that is formed by the fusion of the lower unit. When the receptor is stimulated, cleavage of an alpha sub-unit occurs in the G-protein, and this subunit stimulates the adenylyl-cyclase bound to the inner surface of the ciliary membrane close to the receptor cell body. Activated cyclase then converts multiple adenosine triphosphate molecules into cyclic adenosine monophosphate (cAMP). Finally, cAMP activates the "closed" sodium channel, which is another neighboring membrane protein, to allow the flow of sodium ions into the cell cytoplasm. Sodium ions create positive charge on the inner surface of the cellular membrane, stimulating the olfactory neuron. The resultant action potentials are transmitted to the central nervous system via the olfactory nerves [23].

Although IDA is a common clinical condition associated with multiple comorbidities, studies evaluating its effect on the olfactory function are limited. Our literature search has not revealed any studies in pediatric patients, while one study involved adult patients [7], and others involved animal models [6].

In our patients with IDA the odor threshold, odor discrimination, and odor identification test scores were significantly lower as compared to controls. This observation may be explained on the basis of the effects of iron molecule on the olfactory system. It has been already mentioned that the olfactory receptors belong to the $\mathrm{G}$ protein-coupled receptor family. Also, olfactory sensory neurons are in close association with the cilia. Several iron-dependent enzymes responsible for the transmission of olfactory stimuli play an active role in the olfactory physiology [6]. Neuronal nitric oxide synthase, tryptophan dioxygenase, indoleamine 2,3-dioxygenase, 3-hydroxyanthranilic acid oxygenase, and tyrosine hydroxylase represent the main enzymes involved in the transmission of olfactory stimuli. In experimental studies, rats with iron deficiency anemia were shown to have significant reduction in cranial and olfactory functions [6]. It has been hypothesized that the iron deficiency leads to a loss of function in iron-dependent enzymes, leading to impairment in olfactory signal transmission pathways, and consequently to impaired olfactory functions [24]. Furthermore, IDA may also cause olfactory dysfunction via the associated effects on the cognitive functions.

The association between IDA and reduced appetite

One of the most prominent clinical features of IDA is reduced appetite, although its mechanisms are unclear [18]. Although dysphagia, atrophic glossitis, angular stomatitis, Plummer-Vinson syndrome, and reduced cognitive performance are not listed in classical textbooks as potential causes of reduced appetite in IDA, we believe that these may play a major etiologic role. In our study, IDA patients scored significantly lower CEBQ scores as 
compared to controls (Table 2). Furthermore, one previous study found a significant correlation between appetite and ferritin levels [25].

The association between reduced appetite and olfactory dysfunction: The taste is determined by the physical characteristics and quality of the food, as well as its odor. In our IDA patients exhibiting different levels of reduced appetite based on the CEBQ test, significantly more severe impairment in the olfactory functions was also observed (Figures 1, 2). As such, the Sniffing odor test results also showed significant loss of olfactory function in IDA patients. In subjects with lower olfactory test scores, a parallel decrease in CEBQ scores was observed, suggesting a direct link between olfactory functions and appetite in IDA patients. This was supported by the significant correlations observed in the correlation analysis. Taste of food items cannot be accounted for only on the basis of sweetness. Smell improves the taste and stimulates the appetite by augmenting the taste or flavor of the food [26]. In the same study, an ortho-nasal affect has been described that occurs when the smell of food reaches the orthonasal region. This was clearly shown in the study by Bonfill et al. that involved patients with anosmia [27]. On the other hand, the sense of smell has also been reported to augment the taste effect via an increase in salivation [28], In one study by Rolls and Bayliss, a specific area in the caudo-lateral orbito-frontal cortex of monkeys has been shown to be responsible for both sense of smell and taste perception [29].

In other studies on the same subject, it has been shown that the appetite may be improved by a cephalic phase, in which the smell of food may stimulate the insulin secretion as well as by the stimulation of gastric acid secretion [30]. In one study by Small et al., this was explained on the basis of neuronal mechanisms associated with the integration of the smell and taste [31]. And Seubert et al. studied 2234 older adults and also found olfactory dysfunction to be associated with both a BMI < 18 and poor appetite [32]. Dramatic decrease in appetite associated with conditions that impair the sense of smell, such as the common cold, seem to lend a support to this notion.

Strengths of our study: Exclusion of patients with pediatric psychiatric disorders associated with reduced appetite and impaired olfactory functions is one of the strengths of our study. Furthermore, our sample size is larger compared to other previous studies. Our study is the first to examine both the olfactory functions and the association between sense of smell and appetite in children with IDA.

Limitations of our study: Administration of olfactory tests only prior to the treatment phase represents one limitation of our study, precluding an assessment of a change in olfactory 
functions after treatment. Also, another limitation is the absence of a comparison between IDA patients with or without reduced appetite in terms of olfactory functions.

In conclusion, it was observed that decreased appetite in children with IDA was accompanied by impaired odor functions. It suggests that odor dysfunction may be a significiant factor for decreased appetite. Our study is the first of its kind, in analyzing the relationship between olfactory functions and appetite in children with IDA. While neurological, chemical, molecular, and psychological mechanisms can be proposed as physiological explanations for this relationship, further studies are warranted to shed more light on its physiopathology.

Conflict of Interest: No potential conflict of interest was reported by the authors.

Funding: No funding was received.

\section{REFERENCES}

1. Lanskovsky P. Classification and diagnosis of anemia in children. In: P. Lanskovsky (ed). Manual of pediatric hematology and oncol, 5th ed, Academic Press, London, 2011:1-86.

2. Pala E, Erguven M, Guven S, Erdogan M, Balta T. Psychomotor development in children with iron deficiency and irondeficiency anemia. Food Nutr Bull 2010;31(5):431-5.

3. Booth IW, Aukett MA. Iron deficiency anemia in infancy and early childhood. Arch Dis Child 1997;76:549-54.

4. Küçük Ö, Göçmen AY, Biçer S. Prevalence of Iron Deficiency Anemia şn Children with Poor Appetite. Bozok Med J. 2013,2:(37-41).

5. Öztürk O. Ruh Sağlı̆̆ 1 ve Bozukluklar. Ankara: Nobel Kitabevi, 2001.

6. Ruvin Kumara VM. Influence of Iron Deficiency on Olfactory Behavior in Weanling Rats. J Behav Brain Sci 2012;02:167-175.

7. Dinc ME, Dalgic A, Ulusoy S, Dizdar D, Develioglu O, Topak M. Does iron deficiency anemia affect olfactory function? Acta Otolaryngol. 2016;136(7):754-7.

8. Schecklmann M, Schwenck C, Taurines R, Freitag C, Warnke A, Gerlach M, et al. A systematic review on olfaction in child and adolescent psychiatric disorders. J Neural Transm (Vienna). 2013;120(1):121-30. 
9. Kaufman Birmaher B, Brent D (1997) Schedule for affective disorders and schizophrenia for school-age children-present and lifetime version (K-SADS-PL): initial reliability and validity data. J Am Acad Child Adolesc Psychiatry 36: 980-8.

10. Gokler B, Unal F, Pehlivantürk B (2004) The Validity and Reability of Turkish verison of Kiddie Schedule for Affective Disorders and Schizophrenia for School Aged Children- Present and Lifetime Version. Child and Youth Mental Health Journal 11: 109-16.

11. Wardle J, Guthrie CA, Sanderson S, Rapoport L. Development of the children's eating behaviour questionnaire. J Child Psychol Psyc 2001;42:963-70.

12. Yilmaz R, Erkorkmaz Ü. Adaptation study of the Turkish children's eating behavior questionnaire. Anatolian Journal of Psychiatry 2011;12:287-94.

13. Hummel T, Sekinger B, Wolf SR, Pauli E, Kobal G 'Sniffin' Sticks': olfactory performance assessed by the combined testing odor identification, odor discrimination and olfactory threshold. Chem Senses 1997;22:39-52.

14. Doty RL. Olfactory dysfunction in Parkinson disease. Nat Rev Neurol 2012;8:329-39.

15. Fusetti M, Fioretti AB, Silvagni F, Simaskou M, Sucapane P, Necozione S, Eibenstein A. Smell and Preclinical Alzheimer Disease: Study of 29 Patients with Amnesic Mild Cognitive Impairment. Journal of Otolaryngology Head and Neck Surgery. 2010;39(2):175-81.

16. Kovacs T. Mechanisms of Olfactory Dysfunction in Aging and Neurodegenerative Disorders. Ageing Research Reviews. 2004; 3(2):215-32.

17. Worldwide prevalence of anaemia 1993-2005: WHO global database on anaemia. Edited by Bruno de Benoist, Erin McLean, Ines Egli, Mary Cogswell. Geneva World Health Organization.

18. Özdemir N. Iron deficiency anemia from diagnosis to treatment in children. Turk Pediatri Ars. 2015;50(1):11-19.

19. Nathan RA, Eccles R, Howarth PH, Steinsvag SK, Togias A. Objective monitoring of nasal patency and nasal physiology in rhinitis. J Allergy Clin İmmunol 2005;115:44259.

20. Probst R, Grevers G, Iro H. Basic Physiology and Immunology of the Nose. In: Basic Otolaryngology. Stutgart. New York. Thime; 2006;10-13.

21. Drake L A. Scott Brown's Otolaryngology, 6.th.ed. Oxford, Buttervorth Heinemann; 1997.p.1/6/1-16.

22. Karasalihoğlu AR. Kulak burun boğaz hastalıkları ve baş boyun cerrahisi. 3. baskı. Ankara: Güneş Kitabevi, 2002:97-114.

23. Guyton AC. Olfactory physiology. Text Book of Medical Physiology. Guyton AC, Hall CE (ed). 10's edn. W.B. Saunders company. 2001: 616-9.

24. Kuriyan M, Carson JL. Anemia and clinical outcomes. Anesthesiol Clin North America 2005;23:315-25. 
25. Topaloğlu AK, Hallioğlu O, Canim A, Düzovalı Ö, Yilgor E. Lack of association between plasma leptin levels and appetite in children with iron deficiency. Nutrition 2001;17(7-8):657-9.

26. Prescott J. Flavour as a psychological construct: implications for perceiving and measuring the sensory qualities of foods. Food Qual Prefer 1999;10:349-56.

27. Bonfils P, Avan P, Faulcon P, Malinvaud D. Distorted odorant perception: analysis of a series of 56 patients with parosmia. Arch Otolaryngol Head Neck Surg 2005;131:107- 12 .

28. Rogers PJ, Hill AJ. Breakdown of dietary restraint following mere exposure to food stimuli: interrelationships between restraint, hunger, salivation, and food intake. Addict Behav 1989;14:387-97.

29. Rolls ET, Bayliss LL. Gustatory, olfactory, and visual convergence within the primate orbitofrontal cortex. Journal of Neuroscience 1994;14:5437-52.

30. Feldman M, Richardson CT. Role of thought, sight, smell, and taste of food in the cephalic phase of gastric acid secretion in humans. Gastroenterology 1986;90:428-33.

31. Small DM, Prescott J. Odor/taste integration and the perception of flavor. Exp Brain Res 2005; 166:345-57

32. Seubert J, Laukka EJ, Rizzuto D, Hummel T, Fratiglioni L, Backman L, et al. Prevalence and Correlates of Olfactory Dysfunction in Old Age: A Population-Based Study. J Gerontol A Biol Sci Med Sci. 2017;72:1072-9. 